\title{
DEWOLUCJA JAKO SZCZEGÓLNY PROCES DECENTRALIZACJI W WIELKIEJ BRYTANII
}

\section{DEVOLUTION AS A SPECIAL PROCESS OF DECENTRALIZATION IN THE UK}

\section{Streszczenie}

Po objęciu władzy przez New Labour w Zjednoczonym Królestwie Wielkiej Brytanii i Irlandii Północnej został zapoczątkowany szczególny proces decentralizacji i politycznej regionalizacji określany pojęciem dewolucji. Dewolucja jest określeniem procesu specyficznego, wyjątkowego i charakterystycznego dla przemian zachodzących w Zjednoczonym Królestwie. Używanie go w odniesieniu do procesów decentralizacyjnych zachodzących w innych państwach, w tym Polsce nie wydaje się być właściwe. Dewolucja jako proces decyduje o obecnym i przyszłym kształcie Zjednoczonego Królestwa. Czyni proces wyjścia z UE skomplikowanym i ryzykownym politycznie.

Słowa kluczowe: dewolucja; decentralizacja władzy.

\begin{abstract}
Taking power by New Labour in the United Kingdom of Great Britain and Northern Ireland marked the beginning of a special process of decentralization and political regionalization referred to as the concept of devolution. The term devolution enhances the specific, unique and characteristic process of changes that take place in the United Kingdom. Using it in relation to the decentralization processes occurring in other countries, including Poland, does not seem to be appropriate. Devolution as
\end{abstract}


a process determines the current and future shape of the United Kingdom. It makes the process of exit from the EU complicated and politically risky.

Key words: devolution; decentralization of power.

\section{Wstęp}

Zjednoczone Królestwo jest uważane za państwo unitarne, posiadające jedno źródło władzy konstytucyjnej: Parlament Westminsterski. Bywa też określane jako „unia"l. Odnosi się to do sposobu, w jakim historycznie powstało. Najpierw Anglia stała się monarchią zjednoczoną. W okresie od XIII wieku do Aktów Zjednoczenia w XVI wieku wchłonęła w swój system polityczny i administracyjny Walię tolerując istnienie odmiennego języka i kultury walijskiej. W latach sześćdziesiątych XX wieku w ramach pewnej dewolucji administracyjnej w Walii ustanowione zostało Biuro Walijskie i wyznaczono Sekretarza Stanu dla Walii. Szkocja była odrębnym państwem aż do Aktu Zjednoczenia z 1707 roku. Akt ten zniósł zarówno angielski, jak i szkocki parlament i utworzył nowy parlament Wielkiej Brytanii. Szkocji zezwolono na pozostawienie jej systemu prawnego (rzymskiego), systemu edukacyjnego, kościoła (kalwinistycznego raczej niż anglikańskiego). Pod koniec XIX wieku (1885) zostało ustanowione Biuro Szkockie pod przewodnictwem Sekretarza Szkocji, który w 1926 roku stał się Sekretarzem Stanu Szkocji. Biura Szkockie i Walijskie były odpowiedzialne za szeroki zakres usług (chociaż każde w innym zakresie) i stanowiły formę dewolucji administracyjnej. Zarówno w Szkocji jak i w Walii był to rodzaj władzy zdecentralizowanej, która nie była bezpośrednio odpowiedzialna przed ludnością. Irlandia od 1801 roku (Akt Zjednoczenia) była zarządzana z zamku w Dublinie i przez irlandzkich posłów w Westminsterze. Po podziale wyspy w 1920 roku - Północna Irlandia, pozostając w unii z Wielką Brytanią miała własny rząd i parlament. Z powodu licznych starć między ludnością protestancką a mniejszością katolicką w 1972 roku parlament Północnej Irlandii został zniesiony i wprowadzono bezpośrednie rządy brytyjskie za pośrednictwem Sekretarza Stanu do spraw Północnej Irlandii. Zasadniczy konflikt dotyczył ,problemu konstytucyjnego” - czy Północna Irlandia

1 J. Loughlin, The United Kingdom: From Hypercentralization to Devolution, [w:] J. Loughlin i in. (red.), Subnational Democracy in the European Union. Challenges and Opportunities, Oxford 2001, s. 38; P. Sarnecki, Ustroje konstytucyjne państw współczesnych, wyd. II, Kraków 2005, s. 30. 
powinna pozostać w Zjednoczonym Królestwie, czy powinna być przyłączona do Republiki Irlandii. Obecnie rządy Wielkiej Brytanii i Republiki Irlandii zaakceptowały odmienność Północnej Irlandii, co znalazło wyraz w układzie pokojowym z 1998 roku zwanym Good Friday Agreement ${ }^{2}$.

Relacje czterech części państwa brytyjskiego wobec władzy centralnej nigdy nie były jednolite. Szkocja, Walia i Północna Irlandia przystąpiły do unii z Anglią w różnych okolicznościach i na podstawie odmiennych aktów prawnych. Większość centralnego ustawodawstwa obejmowało Anglię i Walię, natomiast dla Szkocji i Północnej Irlandii często konieczne były odrębne akty prawne. Istnienie różnych systemów prawnych w państwie brytyjskim jest zatem następstwem ,historii politycznej, a w tym rozwiązań przyjmowanych w czasach godzenia się na unię oraz rozwiązań przyjmowanych później dla różnych części państwa" "Zróżnicowanie poszczególnych części Zjednoczonego Królestwa zwiększyło się w wyniku dewolucji, tj. zapoczątkowanego przez New Labour szczególnego procesu decentralizacji ${ }^{4}$.

Celem opracowania jest przedstawienie charakterystyki brytyjskiej dewolucji i próba wykazania, że dewolucja jest określeniem procesu specyficznego, wyjątkowego i charakterystycznego dla przemian zachodzących w Zjednoczonym Królestwie. Używanie go w odniesieniu do procesów decentralizacyjnych zachodzących w innych kontynentalnych państwach europejskich, w tym w Polsce nie jest właściwe. Opracowanie składa się z dwóch części oraz zakończenia. W pierwszej części omówione zostały trzy modele dewolucji brytyjskiej: szkocki, walijski i północnoirlandzki. W drugiej części wskazano na cechy brytyjskiej dewolucji. Zakończenie zawiera podsumowanie, konkluzje oraz krótkie odniesienie do sytuacji po referendum w sprawie Brexitu z czerwca 2016 roku.

2 J. Loughlin, The United Kingdom: From..., s. 38-39; Encyklopedia Popularna PWN, wyd. XXI, Warszawa 1991, s. 324-325. Zob. też: L. Rajca, Reformy samorzadu terytorialnego w Anglii w latach 1997-2010, Toruń 2012, s. 62-63.

3 C. Munro, Studies in Constitutional Law, Londyn 1999, s. 16, cyt. za: J. Supernat, Dewolucja w Zjednoczonym Królestwie Wielkiej Brytanii i Irlandii Pólnocnej, „Samorząd Terytorialny" 2012, nr 1-2, s. 135.

$4 \quad$ O dewolucji jako o rodzaju decentralizacji rządów i procesu stanowienia prawa pisze Hilaire Barnett: H. Barnett, Constitutional and Administrative Law, $4^{\text {th }}$ ed., London 2003. 


\section{Trzy modele dewolucji ${ }^{5}$}

W ramach brytyjskiej dewolucji największy zakres uprawnień uzyskał Parlament Szkocki. Szkocja to nie tylko region, któremu nadano autonomię, ale w istocie Królestwo Szkocji wcielone do Unii brytyjskiej w 1707 roku. Zasadniczą determinantą wdrożenia reformy dewolucyjnej w Szkocji było osłabienie i ,ucywilizowanie" istniejących tam tendencji odśrodkowych ${ }^{6}$. Kompetencje Parlamentu Szkockiego obejmują ustawodawstwo we wszystkich materiach, z wyjątkiem tych, które zostały wyraźnie pozostawione regulacji parlamentu Zjednoczonego Królestwa. Ustawa z 1998 roku (Scotland Act) postanawia, iż w gestii Parlamentu Westminsterskiego pozostają konstytucyjne kwestie, takie jak ustrój, sprawy zagraniczne, obronność, służba cywilna, rejestracja partii politycznych. Można więc przyjąć, że ustawa o Szkocji z 1998 roku sformułowała domniemanie kompetencji Parlamentu Szkockiego w sprawach dotyczących Szkocji. Ustawa ta przewidywała szereg zastrzeżeń i ograniczeń materialnych dotyczących ustawodawstwa szkockiego, które jednak mogą być zmieniane aktami rządu brytyjskiego. Prawo stanowienia ustaw szkockich nie przekreśla prawa parlamentu Zjednoczonego Królestwa do stanowienia praw obowiązujących w Szkocji we wszystkich sprawach, zarówno podlegających dewolucji, jak i zastrzeżonych ${ }^{7}$.

Najmniejszy zakres autonomii otrzymała Walia. Proces decentralizacji nie był tam stymulowany oddolną inicjatywą, gdyż społeczeństwo walijskie nie przejawiało tendencji separatystycznych, a nawet nie miało ukształtowanego

5 W tym fragmencie opracowania częściowo wykorzystuję mój artykuł: L. Rajca, Ksztaltowanie się autonomii terytorialnej w Wielkiej Brytanii i wybranych państwach europejskich, [w:] J. Iwanek, R. Radek (red.), Autonomia terytorialna w perspektywie europejskiej, t. 2, Toruń 2014, s. 56-64.

$6 \quad$ B.H. Toszek, E. Kużelewska, Od wizji do rzeczywistości. Dziesięć lat dewolucji w Walii, Warszawa 2011, s. 7.

$7 \quad$ Należy tu jednak wskazać na konwenans Sewela (Sewel Convention), zgodnie z którym wydawanie ustaw przez parlament Zjednoczonego Królestwa dotyczących Szkocji, winno, co do zasady, być poprzedzone uzyskaniem zgody parlamentu szkockiego. Zob.: S. Kubas, Parlament Szkocki. Dewolucja - wyzwanie dla Zjednoczonego Królestwa, Warszawa 2004, s. 106. W praktyce wnioski Sewela były często wykorzystywanym instrumentem, co oceniano jako podważanie sensu dewolucji. Z drugiej strony, sprawy których dotyczyły były w większości przypadków mało kontrowersyjne i spotykały się z jednogłośną akceptacją szkockich parlamentarzystów. T. Czapiewski, Co dalej z dewolucją? Współczesne projekty zmian ustrojowej pozycji Szkocji, [w:] F. Gołembski i in. (red.), Polityka brytyjska po wyborach parlamentarnych 2010, Warszawa 2011, s. 238. 
poczucia świadomości narodowej na płaszczyźnie politycznej. Wprowadzenie reformy dewolucyjnej wynikało raczej z obawy przed rosnącym wpływem partii nacjonalistycznych, zwłaszcza Plaid Cymru, a także stanowiło element gry wyborczej ukierunkowanej na ugruntowanie popularności Partii Pracy wśród Walijczyków ${ }^{8}$. Na podstawie Government of Wales Act 1998 zostało utworzone Zgromadzenie Narodowe Walii (National Assembly for Wales), posiadające wyłącznie pochodną władzę prawodawczą, a więc wykonawczą wobec ustaw brytyjskich i ogólną kompetencję do nadzorowania realizacji ustaw brytyjskich i wydawania w tym zakresie wytycznych. Inaczej niż w przypadku Szkocji, w ustawie o rządzie Walii z 1998 roku wyróżnione zostały sfery do uregulowania na poziomie walijskim ${ }^{9}$. Początkowo kompetencje Zgromadzenia Narodowego i powiązanego z nim (tworzącego z punktu prawnego jeden organ) Komitetu Wykonawczego ograniczały się do posiadanych pierwotnie przez Sekretarza Stanu do spraw Walii. Ich decyzje wymagały każdorazowo uzyskania zgody parlamentu brytyjskiego. W 2002 roku wyodrębniony został gabinet, ale „nie odpowiadał on pojęciu „rządu miejscowego”, gdyż zasadniczo był ciałem zastępującym Zgromadzenie, kontynuującym jego działalność wykonawczą"10.

Zarówno walijska, jak i szkocka dewolucja otrzymywały sygnały poparcia. Reforma dewolucyjna w Walii zapewniła lepsze warunki rozwoju kultury i języka narodowego Walii, co niewątpliwie przyczyniło się do zwiększenia poczucia tożsamości narodowej. Komisja pod przewodnictwem Lorda Richarda of Ammanford (tzw. Richard Commission) doprowadziła do rozszerzenia kompetencji legislacyjnych Zgromadzenia Walijskiego, co nastąpiło ustawą o rządzie Walii z 2006 roku (Government of Wales Act 2006). Ustawa weszła w życie w maju 2007 roku i odtąd zaczęła obowiązywać przewidziana w niej separacja władzy między Walijskim Zgromadzeniem Narodowym a Rządem Zgromadzenia Walijskiego. Ustawa ta zwiększyła kompetencje prawodawcze Zgromadzenia $w$ trzech dziedzinach (art. 93-102) ${ }^{11}$. Po pierwsze, otrzymało ono szersze uprawnienia do uchwalania prawa wtórnego. Po drugie, przyzna-

$8 \quad$ B.H. Toszek, E. Kużelewska, Od wizji do rzeczywistości..., s. 77, 174.

9 The Government of Wales Act 1998 Schedule 2, http://www.legislation.gov.uk/ukpga/1998/38/contents, (dostęp: 10.02.2009 r.).

10 P. Sarnecki, System konstytucyjny Zjednoczonego Królestwa Wielkiej Brytanii i Irlandii Pótnocnej, Warszawa 2009, s. 47.

11 Szerzej: M. Kaczorowska, Reformy dewolucyjne w Zjednoczonym Królestwie, [w:] F. Gołembski, P. Biskup, M. Kaczorowska (red.), Era Blaira i Browna. Wybrane problemy polityczne rządów Partii Pracy w Zjednoczonym Królestwie 1997-2010, Warszawa 2010, s. 96. 
no mu kompetencje do stanowienia tzw. „środków prawnych Zgromadzenia" (Measures of the National Assembly for Wales) o charakterze prawa pierwotnego, czyli swego rodzaju quasi-ustaw. Projekt aktu prawnego Zgromadzenia Walijskiego wymagał uzyskania zgody Sekretarza Stanu do spraw Walii w rządzie Zjednoczonego Królestwa. Uzyskanie zgody tego Sekretarza było niezbędne do zgłoszenia projektu aktu jednocześnie w Zgromadzeniu Walijskim oraz w parlamencie brytyjskim. To oznacza, że o stanowieniu prawa w Walii ostatecznie decydowała władza centralna Zjednoczonego Królestwa. Nowością na korzyść samodzielności był wymóg obligatoryjnej zgody Zgromadzenia na dokonywanie jakichkolwiek zmian w zakresie przyznanych kompetencji.

Trzeci sposób zwiększenia kompetencji prawodawczych Zgromadzenia został określony w artykułach 103-107 Government of Wales Act z 2006 roku. Przewidywały one możliwość nadania (po referendum) Walijskiemu Zgromadzeniu kompetencji do stanowienia prawa pierwotnego w formie ustaw, ale inaczej niż w Szkocji, nie w każdej sprawie niezastrzeżonej na rzecz Parlamentu Westminsterskiego a jedynie w zakresie spraw wymienionych w załączniku nr 7 do tej ustawy. W zakresie uprawnień ustawodawczych Zgromadzenia miały być też przepisy przewidujące wykonanie ,środka prawnego Zgromadzenia”. Wejście w życie ustawy Government of Wales Act 2006 spowodowało przekształcenie ,administracyjnego modelu dewolucji” w strukturę zbliżoną pod względem organizacyjnym i funkcjonalnym do struktur regionalnych w Szkocji i Irlandii Północnej ${ }^{12}$. Należy dodać, że niewielkie formalne uprawnienia Zgromadzenia Walijskiego były w okresie rządów Labour Party uzupełniane o powiązania partyjne i kontakty indywidualne.

Na podstawie artykułu 103 Government of Wales Act z 2006 roku - w marcu 2011 w Walii odbyło się referendum w sprawie zwiększenia uprawnień legislacyjnych Zgromadzenia Walijskiego w zakresie przewidzianym w tej ustawie. Za zwiększeniem uprawnień opowiedziało się 63,49\% Walijczyków przy frekwencji 35,4\%. Wynik referendum oznacza zasadniczą zmianę charakteru dewolucji w Walii z quasi-ustawodawczej na ustawodawczą. Należy jednak pamiętać, że zgodnie z artykułem 93 ustęp 5 Government of Wales Act z 2006 roku - stanowienie przez Zgromadzenie ustaw nie wpływa na uprawnienia Parlamentu Zjednoczonego Królestwa do stanowienia prawa w sprawach Walii. W rezultacie, parlament brytyjski nadal może unieważnić każdą ustawę National Assembly lub uchwalić ją samodzielnie, gdyby spotkał się z odmową

12 B.H. Toszek, E. Kużelewska, Od wizji do rzeczywistości..., s. 112. 
jej wydania. Wynik referendum zachęcił do otwarcia kolejnego etapu dewolucji walijskiej. Powołana w październiku 2011 roku Komisja ds. Dewolucji w Walii (tzw. Silk Commission) rekomendowała przekazanie Walii dalszych kompetencji. W 2014 roku na mocy Wales Act 2014 Zgromadzenie Walijskie otrzymało więcej kompetencji finansowych, polegających na uprawnieniach do zaciągania pożyczek, możliwości zastąpienia niektórych należności podatkowych nowymi walijskimi podatkami oraz wprowadzenia walijskiego podatku dochodowego będącego przedmiotem referendum. Pomimo tego, że Walia ma obecnie spory zakres kompetencji, to najważniejsze z nich wciąż pozostają w gestii władz w Londynie.

Mimo niskiej frekwencji wynik referendum, jak się wydaje, można zinterpretować jako sukcesywny wzrost zainteresowania Walijczyków samostanowieniem o sprawach regionu. Jak piszą Bartłomiej H. Toszek i Elżbieta Kużelewska, „w ciągu zaledwie jednej dekady społeczność walijska określana przez swoich angielskich sąsiadów mianem ,małych ludzi, o małym intelekcie i małych aspiracjach"13, przebudziła się do życia politycznego (na płaszczyźnie regionalnej, narodowej i ponadnarodowej), jako w pełni ukształtowany naród, który posiada własną wolę i potrafi ją wyartykułować"14. Etapowy charakter procesu dewolucyjnego w Walii służył kształtowaniu się politycznej świadomości Walijczyków.

Inaczej niż w Walii, w Szkocji odstąpiono od przeprowadzania referendum w sprawie zwiększenia autonomii Szkocji. Nastąpiło to ustawą o Szkocji z 2012 roku, głównie w sprawach fiskalnych w związku z umożliwieniem pożyczania pieniędzy od brytyjskiego ministerstwa finansów i komercyjnych banków oraz przyznaniem Parlamentowi Szkockiemu rozszerzonego prawa nakładania podatków, które jednak nie wejdzie w pełni w życie przed 2016 rokiem. Rozszerzenie dewolucji było przejawem adaptacji systemu politycznego do pojawiających się żądań z otoczenia. Nie było ono jednak wystarczające dla zaspokojenia tych żądań. W październiku 2012 roku David Cameron podpisał porozumienie z premierem Szkocji a jednocześnie szefem nacjonalistycznej Szkockiej Partii Narodowej (SNP) Alexem Salmondem - w sprawie referendum niepodległościowego. W dokumencie opublikowanym w 2013 roku podkreślono, że uzyskanie przez Szkocję niepodległości oznacza koniec dewolucji, gdyż elastyczność dewolucji nie oznacza, że niepodległość będzie jej

13 M. Parker, Neighbours from Hell?, Talybont 2007, s. 28.

14 B.H. Toszek, E. Kużelewska, Od wizji do rzeczywistości..., s 177. 
rozszerzeniem ${ }^{15}$. Jesienią 2014 roku Szkoci zdecydowali o pozostaniu w Zjednoczonym Królestwie. Przy bardzo wysokiej frekwencji $(84,6 \%)$ większość $(55,3 \%)$ Szkotów opowiedziała się przeciwko wystąpieniu z Wielkiej Brytanii. Referendum to miało charakter tylko konsultacyjny. Jedynym organem władnym do przyznania Szkocji niepodległości jest Parlament Westminsterski. Powołana nazajutrz po referendum niepodległościowym Komisja Smitha (Smith Commission) rekomendowała przekazanie Szkocji dalszych kompetencji, co nastąpiło ustawą o Szkocji z 2016 roku (Scotland Act 2016). Na jej podstawie Szkocja uzyskała uprawnienie do ustalania stawek podatku dochodowego i progów podatkowych, kontrolowania istotnej części systemu welfare oraz wiele innych kompetencji, które - jak powiedział David Cameron - „czynią Holyrood jednym z najsilniej zdecentralizowanych (devolved) parlamentów na świecie"16.

Odmienny przypadek stanowi Irlandia Północna, gdzie przyjęcie rozwiązań dewolucyjnych komplikuje trudna sytuacja polityczna. Napięcia występują na tle dążeń separatystycznych, mniejszość irlandzka nie zaakceptowała podziału wyspy z 1920 roku i dąży do przyłączenia sześciu hrabstw północnej prowincji Ulsteru do Republiki Irlandii. Podstawą do dewolucji władzy centralnej w Północnej Irlandii była ustawa o Północnej Irlandii z 1998 roku (Northern Ireland $A c t$ ). Ustawa ta powołała organ ustawodawczy o nazwie Zgromadzenie Północnej Irlandii (The Northern Ireland Assembly). Zgromadzenie jest organem, na rzecz którego dokonano dewolucji władzy ustawodawczej i wykonawczej - przekazane uprawnienia były tu nieco węższe niż w przypadku uprawnień Szkockiego Parlamentu. W odróżnieniu od Walii i Szkocji, w przypadku Irlandii Północnej wydzielono trzy kategorie spraw ${ }^{17}$ : zastrzeżone (reserved), które z czasem będą mogły być przekazane do rozstrzygnięcia Irlandii Północnej za zgodą (brytyjskiego) Sekretarza Stanu dla Północnej Irlandii; wyłączone (excepted), które wyraźnie nie należą do Zgromadzenia; i przekazane (transfered), które zostały już przekazane w drodze dewolucji Zgromadzeniu Północnoirlandzkiemu. Także i tu, akty rządu brytyjskiego mogą zmieniać ów wykaz uprawnień.

15 Scotland analysis. Devolution and the implication of Scottish independence, https://www. gov.uk/government/publications/scotland-analysis-devolution-and-the-implications-ofscottish-independence, (dostęp: 1.02.2014 r.).

16 Scotland Act receives Royal Assent and now becomes law, https://www.gov.uk/government/ news/scotland-bill-completes-its-passage-through-parliament, (dostęp: 20.06.2016 r.).

17 M. Kaczorowska, Reformy dewolucyjne... s. 89. 
Irlandzka droga do autonomii nie rozwijała się bez przeszkód. Zgromadzenie Północnej Irlandii i Egzekutywa zostały zawieszone w październiku 2002 roku z powodu konfliktu między unionistami a republikanami. Porozumienie zawarte w maju 2007 roku, zakończyło blisko 5-letni okres rządów bezpośrednich z Londynu w Irlandii Północnej. W marcu 2009 roku, a potem w lutym 2010 roku okazało się jednak, że zagrożenie stanowią wciąż dysydenckie grupy zbrojne republikanów, odrzucające ustalenia procesu pokojowego z 2007 roku. Dewolucja dalszych kompetencji wydaje się zależeć od skonsolidowanego procesu pokojowego. W kwietniu 2010 roku nastąpił bardzo ważny etap dewolucji, polegający na przekazaniu władzy sądowniczej i policyjnej Zgromadzeniu Północnej Irlandii ${ }^{18}$.

Dewolucja nie objęła w pełni całego Zjednoczonego Królestwa. Poza reformą decentralizacyjną z 1998 roku pozostała zasadniczo Anglia, z wyjątkiem metropolii londyńskiej, gdzie w 1999 roku został powołany wybieralny samorząd Londynu - Greater London Authority. Anglia jako jedyna część państwa brytyjskiego nigdy nie wykazywała dążeń do uzyskania autonomii czy tendencji separatystycznych ${ }^{19}$. A zatem, największy obszar, o największej aktywności gospodarczej i największej liczbie populacji (prawie 85\%) pozostaje pod kontrolą rządu centralnego. Anglia nadal jest rządzona poprzez prawa dla Anglii, które są stanowione w parlamencie westminsterskim przez członków parlamentu pochodzących ze wszystkich części Zjednoczonego Królestwa. Zgłaszane były jednak postulaty pewnego rodzaju dewolucji na rzecz regionów lub subregionów. Koncepcja dewolucji w regionach angielskich poniosła jednak fiasko, gdyż ludność angielska nie wsparła inicjatywy władz centralnych dotyczącej przekazania uprawnień politycznych z centrum do wybieralnych władz regionalnych.

Dewolucja dokonała ogromnych przemian politycznych i ustrojowych w Zjednoczonym Królestwie. Walia, Szkocja i Północna Irlandia uzyskały daleko idącą niezależność. W Zjednoczonym Królestwie trudno mówić o dewolucji władzy sądowniczej. Od 2005 roku naczelnym organem sądowym dla całej Wielkiej Brytanii jest Sąd Najwyższy. Dla całej Wielkiej Brytanii wspólnymi sądami są również Sąd Wojskowy i Apelacyjny Sąd Wojskowy ${ }^{20}$.

18 M. Anderson, Devolution of Policing and Justice in Northern Ireland, "The Ombudsman" 2010, nr 40, s. 1, 16.

19 Anglicy, w przeciwieństwie do Szkotów czy Walijczyków zdecydowanie częściej uważają się za Brytyjczyków niż za Anglików.

20 Szerzej: G. Libor, Zjawisko dewolucji władzy i jego charakterystyka na przykładzie Walii: wymiar instytucjonalno-prawny, „Wrocławskie Studia Politologiczne” 2014, t. 16, s. 166. 


\section{Specyfika brytyjskiej dewolucji}

Dewolucja jest określeniem procesu szczególnego, wyjątkowego i charakterystycznego dla przemian zachodzących w Zjednoczonym Królestwie. W wymiarze politycznym i prawnym polega na przekazywaniu części kompetencji władzy centralnej, zarówno kompetencji ustawodawczych jak i wykonawczych w różnym zakresie, podporządkowanym, wybranym demokratycznie organom przedstawicielskim i rządom w Szkocji, Walii i Północnej Irlandii ${ }^{21}$. Istota dewolucji polega na tym, że władza zostaje $\mathrm{w}$ tym procesie przekazana (devolved), a nie oddana (transferred), gdyż suwerenny parlament Zjednoczonego Królestwa nie wyrzeka się ostatecznie swojej władzy ${ }^{22}$. $\mathrm{W}$ procesie dewolucji nie następuje podział suwerenności, a instytucje powstałe w wyniku dewolucji nie posiadają zinstytucjonalizowanej roli w procesie tworzenia polityki centralnej. Specyfika dewolucji jako szczególnego rodzaju decentralizacji polega na pozostawieniu organom centralnym możliwości podejmowania decyzji w sprawach przekazanych w drodze dewolucji. Parlament Westminsterski może uchylić każde prawo, w tym ustawy dewolucyjne, należące do najważniejszych obszarów brytyjskiego systemu konstytucyjnego i to w zwykłej procedurze legislacyjnej. Nierównowaga pozycji między organami regionalnymi a organami Zjednoczonego Królestwa w znacznym stopniu wynika z braku konstytucji w rozumieniu kontynentalnym, która stanowi formalną gwarancję pozycji regionów. $Z$ dotychczasowego przebiegu dewolucji wynika, że kwestia pogodzenia samodzielności Szkocji, Walii i Irlandii Północnej z omnipotencją Parlamentu Westminsterskiego jest rozstrzygana bardziej na gruncie praktyki politycznej i przesądzana raz po stronie Londynu, to znów po stronie poszczególnych regionów ${ }^{23}$. Zjednoczone Królestwo znacznie częściej korzysta z nieformalnych praktyk i zwyczajów w miejsce spisanych procedur w porównaniu do państw Europy kontynentalnej ${ }^{24}$. Dewolucja dopuszczając cofanie kompetencji z powrotem na szczebel centralny (za zgodą regionalnego

21 M. Kaczorowska, Reformy dewolucyjne..., s. 83.

22 V. Bogdanor, Devolution in the United Kingdom, Oxford 1999, s. 2-3. Ten proces przekazywania władzy Małgorzata Domagała proponuje określić „,zwracaniem kompetencji władczych regionom, które w przeszłości były niepodległymi państwami”. M. Domagała, Rozwiązania autonomii terytorialnej w Wielkiej Brytanii, [w:] J. Iwanek, R. Radek (red.), Autonomia terytorialna w perspektywie europejskiej, t. 2, Toruń 2014, s. 36.

23 M. Domagała, Rozwiazania autonomii terytorialnej..., s. 25.

24 T. Czapiewski, Ksztaltowanie się systemu politycznego Szkocji, Szczecin 2011, s. 195, 299. 
ciała ustawodawczego) przewiduje elastyczność uregulowań prawnych. Ta elastyczność jest cechą brytyjskiej dewolucji.

W związku ze sposobem tworzenia Zjednoczonego Królestwa poszczególne jego części - jak wspomniano we wstępie - były niejednolite pod względem posiadanych praw. Niejednolitość ta określana jest jako asymetryczność 25 . Dewolucja brytyjska ma również asymetryczny charakter, co stanowi istotny wyróżnik brytyjskiego modelu decentralizacji regionalnej. Asymetryczność ta przejawia się po pierwsze $\mathrm{w}$ tym, że nie objęła w pełni całego Zjednoczonego Królestwa, a jedynie terytorium zamieszkałe przez ok. 16\% ludności całego państwa. Poza reformą decentralizacyjną z 1998 roku - jak wspomniano - pozostała zasadniczo Anglia, zdecydowanie największa terytorialnie i ludnościowo część państwa. Asymetryczny charakter dewolucji powoduje, że parlamentarzyści ze Szkocji, Walii i Irlandii Północnej, zasiadający w Westminsterze, mają prawo decydować o wszelkich sprawach związanych z Anglią, a deputowani angielscy nie mogą się wypowiadać na temat spraw szkockich, walijskich czy północnoirlandzkich. Uzasadnieniem geograficznej asymetryczności jest utrzymująca się odrębność etniczna, kulturowa i językowa oraz administracyjno-prawna (nie licząc Walii) poszczególnych regionów „obrzeża celtyckiego" oraz brak dążeń Anglii do uzyskania autonomii. Po drugie, asymetryczność przejawia się w tym, że w poszczególnych regionach organy przedstawicielskie uzyskały różne kompetencje. Zakres autonomii przyznanej Szkocji, Walii i Północnej Irlandii został uzależniony od stopnia odrębności politycznej, prawnej i administracyjnej tych regionów oraz poczucia tożsamości narodowej ${ }^{26}$. W poszczególnych regionach inna była też pozycja egzekutywy. Na przykład, w Szkocji od początku istniała instytucja pierwszego ministra (premiera) i innych ministrów, odpowiedzialnych przed Parlamentem Szkockim. W Walii, początkowo Walijskie Zgromadzenie Narodowe wybierało ze swego grona Komitet Wykonawczy, który faktycznie stanowił jedną z komisji parlamentarnych (Walijskie Zgromadzenie Narodowe posiadało wówczas przede wszystkim kompetencje administracyjne). Ten rodzaj asymetryczności

25 Ch. Jeffrey, Devolution in the UK, [w:] M. Flinders, A. Gamble, C. Hay, M. Kenny (red.), The Oxford Handbook of British Politics, Oxford, New York 2009, s. 385, cyt. za: K. Wolniaczyk, Szkockie dążenia niepodległościowe - płaszczyzna prawna i polityczna, „Ius Novum" 2014, nr 3, s. 88.

26 B.H. Toszek, Problem labilności przesłanek dewolucji w Walii, [w:] B.H. Toszek i T. Czapiewski (red.), Od Thatcher do Blaira. Wielka Brytania na przełomie XX i XXI wieku, Szczecin 2010, s. 135. 
dewolucji uniemożliwiał prowadzenie jednolitej i wspólnej polityki rządom szczebla regionalnego. Warto dodać, że zgromadzenia parlamentarne w poszczególnych regionach różnią się także rozmiarem i strukturą, a także systemem wyborczym ${ }^{27}$. Trzecim symptomem asymetryczności jest to, że proces rozszerzania (ewoluowania) dewolucji następuje nierównomiernie (w różnym stopniu) i niejednocześnie (w różnym czasie) w poszczególnych częściach Zjednoczonego Królestwa. Dynamika dewolucji uzależniona jest od społecznego poparcia dla rodzaju przekazywanych kompetencji od rządu centralnego. Proces ten opiera się raczej na pragmatycznych rozwiązaniach, a nie na jednej konstytucyjnej, formalnoprawnej formule ${ }^{28}$. Asymetryczny charakter dewolucji to efekt brytyjskiego pragmatyzmu, polegający na praktycznym rozwiązaniu problemów „bez uciekania się do abstrakcyjnych, konstruktywistycznych

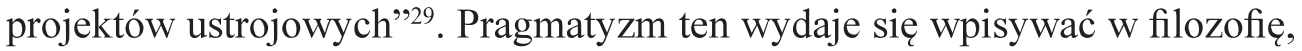
która argumentuje, że potrzebny jest otwarty zdecentralizowany proces prób i błędów, konkurencji i uczenia się by wykorzystać rozproszoną wiedzę $e^{30}$. Wyrażane są też opinie, że rozwiązania te są wyrazem braku spójnej wizji konstytucyjnych reform wprowadzanych przez Labour Party.

Zapoczątkowana przez laburzystów dewolucja ma charakter ewoluujący (nie zaś stan niezmienny). Otwarty charakter dewolucji oznacza możliwość kolejnych rozszerzeń uprawnień przysługujących regionalnym zgromadzeniom parlamentarnym i kontynuację procesu rozluźniania powiązań istniejących między regionami a centralnym ośrodkiem władzy, a w konsekwencji rozwijania aspiracji politycznych ludności „obrzeża celtyckiego”. W pewnym sensie idea dewolucji była wpisana w ustrój Wielkiej Brytanii, która nigdy nie była klasycznym państwem unitarnym, ale unią państw, które mimo ścisłości politycznego związku i kulturowych podobieństw zachowywały odrębność

27 Wybory do Zgromadzenia Narodowego Walii i Parlamentu Szkockiego odbywają się w systemie dodatkowego mandatu (additional member system, AMS), do Zgromadzenia Północnej Irlandii w systemie pojedynczego głosu przechodniego (single transferable vote, STV), natomiast wybory do parlamentu krajowego w systemie first-past-the-post.

28 M. Galent, Asymetryczna dewolucja w Zjednoczonym Królestwie. Walijczyków droga do autonomii, [w:] J. Iwanek, R. Radek (red.), Autonomia terytorialna w perspektywie europejskiej, t. 2, Toruń 2014, s. 54.

29 M. Galent, Asymetryczna dewolucja..., s. 38.

30 Szerzej: H.J. Hennecke, Decentralizacja jako model dla Europy. Wymagania systemowo-teoretyczne i niemieckie doświadczenia z samorządem regionalnym i gospodarczym, [w:] A. Lutrzykowski (red.), Ustrój terytorialny państwa a decentralizacja systemu władzy publicznej, Toruń 2012, s. 249-252. 
państwowo-prawną i wiele zwyczajowych. W literaturze podkreśla się, że w wyniku dewolucji Wielka Brytania stała się faktycznie quasi-federalnym państwem $^{31}$. Dewolucja w Wielkiej Brytanii, podobnie jak autonomia regionalna we Włoszech i w Hiszpanii są formami rozwoju rozwiązań pośrednich między klasycznym unitaryzmem a klasycznym federalizmem ${ }^{32}$.

\section{Zakończenie}

Podsumowując, proces decentralizacji w formie dewolucji polega na: 1. przekazywaniu (lecz nie oddawaniu) kompetencji należących do władzy centralnej na rzecz regionalnych zgromadzeń parlamentarnych i rządów; 2. pozostawieniu organom centralnym możliwości podejmowania decyzji w sprawach przekazanych w drodze dewolucji; 3. zachowaniu suwerenności i supremacji parlamentu Zjednoczonego Królestwa; 4. asymetryczności polegającej na ograniczonym zasięgu geograficznym, zróżnicowaniu kompetencji przysługujących poszczególnym regionom oraz nierównomiernej dynamice dewolucji; 5. elastyczności procesu dewolucji; 6 . otwartym charakterze. W rezultacie, dewolucja jest określeniem procesu (modelu) decentralizacji specyficznej, wyjątkowej - nieposiadającej odpowiednika na kontynencie europejskim i charakterystycznej dla przemian zachodzących w Zjednoczonym Królestwie. Wprowadzony w 1998 roku asymetryczny i skomplikowany system (każda część państwa jest rządzona według innych zasad) był wyraźnie odmienny od zarówno belgijskiego i niemieckiego federalizmu jak i decentralizacji na sposób francuski ${ }^{33}$. To, co wyraźnie odróżnia brytyjską dewolucję od procesów decentralizacyjnych w innych państwach to jej asymetryczność w różnych wymiarach. Niektórzy brytyjscy badacze twierdzili, że Szkocja uzyskała w 1998 roku prawdopodobnie tyle niezależności w Unii, co Bawaria w ramach niemieckiego federalizmu kooperacyjnego, Walia otrzymała mniej autonomii niż hiszpańskie wspólnoty autonomiczne, Irlandia Północna jest bliżej modelu walijskiego niż szkockiego.

31 D. Wilson, C. Game, Local Government in the United Kingdom, 4th edition, Basingstoke 2006, s. 82-86.

32 H. Izdebski, Samorząd terytorialny. Podstawy ustroju i działalności, wyd. 3, Warszawa 2014, s. 14.

33 F. Faucher-King, P. Le Galès, The New Labour Experiment. Change and Reform Under Blair and Brown, Stanford 2010, s. 64-65. 
Zastrzegają oni jednak, że porównania brytyjskiej dewolucji z procesami decentralizacji w innych państwach są uproszczone i wybiórcze ${ }^{34}$.

We współczesnych państwach nie istnieje model czy wzorzec, według którego przebiega decentralizacja władzy. Występuje ona pod wieloma postaciami i może przybierać różne formy: w państwach unitarnych; w państwach federalnych; w państwach opartych na autonomii regionalnej ${ }^{35}$. Autonomię zyskują Szkocja, Walia i Irlandia Północna w wyniku dewolucji. Spotykane są opinie, że dewolucję trudno jest jednoznacznie zaliczyć do procesu autonomizacji na wzór hiszpański, czy włoski, przede wszystkim ze względu na jej asymetryczny charakter ${ }^{36}$. Dewolucja dopuszczając cofanie kompetencji z powrotem na szczebel centralny, ale jedynie za zgodą ciała ustawodawczego powstałego w wyniku reformy dewolucyjnej - jak pisze M. Kaczorowska „przewiduje elastyczność uregulowań prawnych, jakiej nie spotykamy w autonomii czy w państwie federalnym"37. Jak wspomniano, dewolucja jest szczególnym rodzajem decentralizacji, charakterystycznym dla Wielkiej Brytanii. W ujęciu Huberta Izdebskiego, dewolucja w Zjednoczonym Królestwie jest postacią decentralizacji i specyficznej politycznej regionalizacji ${ }^{38}$.

Czy termin dewolucja jest właściwy dla określenia procesu decentralizacji w Polsce? Polskie rozumienie unitarności oznacza odrzucenie zarówno autonomii regionalnej, jak i dewolucji. O ile bowiem, jak podkreśla Hubert Izdebski, federalizm można - w znacznym uproszczeniu - definiować jako decentralizację wszystkich trzech władz, autonomię regionalną jako decentralizację władzy ustawodawczej i wykonawczej, zaś dewolucję jako zastąpienie w pewnym zakresie władz centralnych: ustawodawczej i wykonawczej przez zgromadzenia regionalne, unitaryzm w wydaniu polskim dopuszcza jedynie decentralizację władzy wykonawczej ${ }^{39}$. Nie jest zatem właściwe posługiwanie się terminem „dewolucja” w odniesieniu do procesów decentralizacyjnych w Polsce.

34 M. O'Neill, Britishness and politics: towards a federal future, [w:] M. O'Neill (red.), Devolution and British Politics, London 2004, s. 370.

35 Zob. H. Izdebski, Samorzad terytorialny..., s. 58.

36 M. Kaczorowska, Dewolucja systemu politycznego: istota, wplyw i znaczenie - casus Zjednoczonego Królestwa Wielkiej Brytanii i Irlandii Pótnocnej, [w:] J. Szymanek, M. Kaczorowska, A. Rothert (red.), Ewolucja dewolucja emergencja, Warszawa 2007, s. 117-118.

37 M. Kaczorowska, Reformy dewolucyjne w Zjednoczonym..., s. 104.

38 H. Izdebski, Introduction to Public Administration and Administrative Law, Warszawa 2006, s. 68.

39 H. Izdebski, Samorzad terytorialny..., s. 14. 
Dewolucja wprowadzana w sposób fragmentaryczny wraz z reformami skierowanymi na osiągnięcie różnych celów w odrębnych częściach Zjednoczonego Królestwa powodowała dalsze zróżnicowanie w strukturach instytucjonalnych governance (oraz kompetencjach legislacyjnych, finansowych i dotyczących zarządzania $)^{40}$. Zdaniem niektórych brytyjskich badaczy, w wyniku dewolucji Zjednoczone Królestwo stało się „chwiejącym się, asymetrycznym systemem ewoluującym w kierunku quasi-federalnym na peryferiach [w różnym stopniu zdecentralizowanych - L.R.], ale wysoce scentralizowanym w Anglii" ${ }^{41}$. Polityki zarówno w Szkocji jak i Walii są coraz bardziej odmienne od tych w Londynie i w Anglii. W trzech regionach ,peryferii celtyckich” wzmacniają się tendencje nacjonalistyczne. Mimo że Szkocji nie udało odłączyć się od Zjednoczonego Królestwa, prawdopodobnie nie jest to koniec dążeń do uzyskania przez ten region pełnej suwerenności. Jak trafnie ujął Bartłomiej H. Toszek, „Dewolucja okazała się swoistą puszką Pandory, której otwarcie wywołało skutki daleko wykraczające poza przewidywania zwolenników koncepcji wzmocnienia pozycji ustrojowej regionów"42. Spotykane są poglądy, częściej po referendum przeprowadzonym w czerwcu 2016 roku w sprawie Brexitu $^{43}$, że Wielka Brytania zmierza w kierunku rozpadu państwa.

Autonomia Szkocji, Walii i Północnej Irlandii nie ma charakteru niepodważalnego w sensie prawnym - w praktyce była dotychczas w pełni uznawana i respektowana w sensie politycznym. Podstawowe akty dewolucyjne nie mają żadnej szczególnej mocy i mogą być zmieniane lub znoszone każdą ustawą parlamentu brytyjskiego ${ }^{44}$. Obecnie między brytyjskimi prawnikami toczy się dyskusja, czy brak zgody parlamentarnych zgromadzeń regionalnych może zablokować decyzję o Brexicie - ewentualnie podjętą przez parlament w Londynie. Zdaniem niektórych prawników konwenans Sewela (Sewel Convention), zgodnie z którym wydawanie ustaw przez parlament Zjednoczonego Królestwa dotyczących Szkocji, winno, co do zasady, być poprzedzone uzyskaniem zgody parlamentu szkockiego - nie jest prawnym wymogiem a jedynie politycznym

40 C. Jeffrey, The unfinished business of devolution: seven open question, "Public Policy and Administration" 2007, vol. 22, nr 1, s. 92-108.

41 F. Faucher-King and P. Le Galès, The New Labour Experiment..., s. 68.

42 B.H. Toszek, Puszka Pandory. Niezamierzone konsekwencje reformy dewolucyjnej $w$ Wielkiej Brytanii, Biuletyn Instytutu Zachodniego, Poznań 2012, nr 102.

43 Artykuł został oddany do druku dwa tygodnie po wspomnianym referendum w Wielkiej Brytanii.

44 P. Sarnecki, Ustroje konstytucyjne państw współczesnych, wyd. 5, Warszawa 2013, s. 72. 
oczekiwaniem, że Parlament Zjednoczonego Królestwa będzie respektował konstytucyjną pozycję Szkockiego Parlamentu. A zatem, brak takiej zgody nie będzie prawną przeszkodą do wyjścia Wysp z unijnych struktur. Nie będzie również przeszkodą ustawa o Szkocji z 2016 roku, która jedynie uznaje konwenans, ale nie przekształca go w prawo ${ }^{45}$.

Ustawy dewolucyne zawierają wymóg dostosowania do prawa unijnego. Ustawa o Szkocji z 1998 roku, na przykład, postanawia, że prawo uchwalone przez Szkocki Parlament, które jest niespójne z prawem UE jest nieważne. Zmiana ustawodawstwa dewolucyjnego w związku z wyjściem Wielkiej Brytanii z Unii Europejskiej nie będzie trudna technicznie, ale politycznie ryzykowna. Szkocja i Północna Irlandia, gdzie większość obywateli głosowała przeciw opuszczeniu UE mogą się sprzeciwiać usunięciu prawa unijnego z ich ustawodawstwa. Dewolucja uczyniła proces wyjścia z UE skomplikowanym i ryzykownym politycznie. Brexit prawdopodobnie przyczyni się do wzmocnienia żądań szkockich o niepodległość i doprowadzi do drugiego referendum niepodległościowego ${ }^{46}$. Będzie również zagrożeniem dla irlandzkich procesów pokojowych $^{47}$.

\section{Literatura}

1. Anderson M., Devolution of Policing and Justice in Northern Ireland, "The Ombudsman" 2010, nr 40.

2. Barnett H., Constitutional and Administrative Law, $4^{\text {th }}$ ed., Cavendish Publishing, London 2003.

3. Bogdanor V., Devolution in the United Kingdom, Oxford University Press, Oxford 1999.

4. Czapiewski T., Ksztaltowanie się systemu politycznego Szkocji, Wydawnictwo Zapol, Szczecin 2011.

5. Czapiewski T., Co dalej z dewolucja? Wspólczesne projekty zmian ustrojowej pozycji Szkocji, [w:] F. Gołembski i in. (red.), Polityka brytyjska po wyborach parlamentarnych 2010, Uniwersytet Warszawski, Warszawa 2011.

45 M. Elliott, Can Scotland Block Brexit?, https://publiclawforeveryone.com/2016/06/26/ brexit-can-scotland-block-brexit/, (dostęp: 2.07.2016 r.); R. Hazell and A. Renwick, Brexit: Its Consequences for Devolution and the Union, UCL Constitution Unit Briefing Paper, https://www.ucl.ac.uk/constitution-unit/research/europe/briefing-papers/briefing-paper-3, (dostęp: 3.07.2016 r.).

46 Premier Szkocji Nicola Sturgeon oznajmiła po referendum w sprawie Brexitu, że nie istnieje już Zjednoczone Królestwo, w którym Szkocja w 2014 roku zgodziła się pozostać.

47 J. Murkens, Brexit: The Devolution Dimension, U.K. Const. L. Blog (28th Jun 2016), https://ukconstitutionallaw.org/, (dostęp: 3.07.2016 r.). 
6. Domagała M., Rozwiązania autonomii terytorialnej w Wielkiej Brytanii, [w:] J. Iwanek, R. Radek (red.), Autonomia terytorialna w perspektywie europejskiej, t. II, Wydawnictwo Adam Marszałek, Toruń 2014.

7. Encyklopedia Popularna PWN, wyd. XXI, PWN, Warszawa 1991.

8. Faucher-King F., Le Galès P., The New Labour Experiment. Change and Reform Under Blair and Brown, Stanford University Press, Stanford 2010.

9. Galent M., Asymetryczna dewolucja w Zjednoczonym Królestwie. Walijczyków droga do autonomii, [w:] J. Iwanek, R. Radek (red.), Autonomia terytorialna w perspektywie europejskiej, t. 2, Wydawnictwo Adam Marszałek, Toruń 2014.

10. Hennecke H.J., Decentralizacja jako model dla Europy. Wymagania systemowo-teoretyczne i niemieckie doświadczenia z samorzadem regionalnym i gospodarczym, [w:] A. Lutrzykowski (red.), Ustrój terytorialny państwa a decentralizacja systemu władzy publicznej, Wydawnictwo Adam Marszałek, Torun 2012.

11. Izdebski H., Samorzad terytorialny. Podstawy ustroju i działalności, wyd. 3, LexisNexis, Warszawa 2014.

12. Izdebski H., Introduction to Public Administration and Administrative Law, Liber, Warszawa 2006.

13. Jeffrey Ch., Devolution in the UK, [w:] M. Flinders, A. Gamble, C. Hay, M. Kenny (red.), The Oxford Handbook of British Politics, Oxford University Press, New York, 2009.

14. Jeffrey Ch., The unfinished business of devolution: seven open question, "Public Policy and Administration" 2007, vol. 22, nr 1, s. 92-108.

15. Kaczorowska M., Reformy dewolucyjne w Zjednoczonym Królestwie, [w:] F. Gołembski, P. Biskup, M. Kaczorowska (red.), Era Blaira i Browna. Wybrane problemy polityczne rządów Partii Pracy w Zjednoczonym Królestwie 1997-2010, Uniwersytet Warszawski, Warszawa 2010.

16. Kaczorowska M., Dewolucja systemu politycznego: istota, wplyw i znaczenie - casus Zjednoczonego Królestwa Wielkiej Brytanii i Irlandii Pólnocnej, [w:] J. Szymanek, M. Kaczorowska, A. Rothert (red.), Ewolucja dewolucja emergencja, Dom Wydawniczy Elipsa, Warszawa 2007.

17. Kubas S., Parlament Szkocki. Dewolucja-wyzwanie dla Zjednoczonego Królestwa, Wydawnictwo Sejmowe, Warszawa 2004.

18. Libor G., Zjawisko dewolucji władzy i jego charakterystyka na przykładzie Walii: wymiar instytucjonalno-prawny, „Wrocławskie Studia Politologiczne” 2014, t. 16, s. 156-169.

19. Loughlin J., The United Kingdom: From Hypercentralization to Devolution, [w:] J. Loughlin i in. (red.), Subnational Democracy in the European Union. Challenges and Opportunities, Oxford University Press, Oxford 2001.

20. O’Neill M., Britishness and politics: towards a federal future, [w:] M. O'Neill (red.), Devolution and British Politics, Routledge, London 2004.

21. Rajca L., Ksztaltowanie się autonomii terytorialnej w Wielkiej Brytanii $i$ wybranych państwach europejskich, [w:] J. Iwanek, R. Radek, Autonomia terytorialna w perspektywie europejskiej, t. 2, Wydawnictwo Adam Marszałek, Toruń 2014.

22. Rajca L., Reformy samorzadu terytorialnego w Anglii w latach 1997-2010, Europejskie Centrum Edukacyjne, Toruń 2012. 
23. Sarnecki P., Ustroje konstytucyjne państw wspótczesnych, wyd. 5, Wolters Kluwer, Warszawa 2013.

24. Sarnecki P., System konstytucyjny Zjednoczonego Królestwa Wielkiej Brytanii i Irlandii Pólnocnej, Wydawnictwo Sejmowe, Warszawa 2009.

25. Sarnecki P., Ustroje konstytucyjne państw wspótczesnych, wyd. 2, Kraków: Zakamycze 2005.

26. Scotland analysis. Devolution and the implication of Scottish independence, https://www. gov.uk/government/publications/scotland-analysis-devolution-and-the- implications-ofscottish-independence, (dostęp:1.02.2014 r.).

27. Scotland Act receives Royal Assent and now becomes law, https://www.gov.uk/government/ news/scotland-bill-completes-its-passage-through-parliament, (dostęp: 20.06.2016 r.).

28. Supernat J., Dewolucja w Zjednoczonym Królestwie Wielkiej Brytanii i Irlandii Pótnocnej, „Samorząd Terytorialny” 2012, nr 1-2, s. 134-141.

29. The Government of Wales Act 1998 Schedule 2, http://www.legislation.gov.uk/ukpga/1998/38/contents, (dostęp: 10.02.2009).

30. Toszek B.H., Puszka Pandory. Niezamierzone konsekwencje reformy dewolucyjnej w Wielkiej Brytanii, Biuletyn Instytutu Zachodniego, Poznań 2012, nr 102.

31. Toszek B.H., Kużelewska E., Od wizji do rzeczywistości. Dziesięć lat dewolucji w Walii, ASPRA-JR, Warszawa 2011.

32. Toszek B.H., Problem labilności przestanek dewolucji w Walii, [w:] B.H. Toszek i T. Czapiewski (red.), Od Thatcher do Blaira. Wielka Brytania na przełomie XX i XXI wieku, Wydawnictwo Naukowe Uniwersytetu Szczecińskiego, Szczecin 2010.

33. Wilson D., Game C., Local Government in the United Kingdom, $4^{\text {th }}$ ed., Palgrave Macmillan, Basingstoke 2006.

34. Wlaźlak K., Wspótczesne problemy autonomii regionalnej w Europie, „Państwo i Prawo” 2010, nr 8, s. 31-46.

35. Wolniaczyk K., Szkockie dqżenia niepodległościowe - płaszczyzna prawna i polityczna, „Ius Novum” 2014, nr 3, s. 86-100.

Lucyna Rajca

Uniwersytet Jana Kochanowskiego w Kielcach 